\title{
CIVA-粒子法の非圧縮性流体解析への応用*
}

$$
\text { 田 中伸厚*1 }
$$

\section{Application of CIVA-particle method to incompressible fluid simulation}

\author{
TANAKA Nobuatsu*2 \\ ${ }^{* 2}$ Nuclear Engineering Laboratory, Toshiba Corporation, \\ 4-1 Ukishima-cho, Kawasaki-ku, Kawasaki, 210-0862 Japan
}

\begin{abstract}
This paper presents an application algorithm of CIVA method, which is so flexible as to enable to integrate the CIP, gridless and particle method, to incompressible fluid simulation. The CIVAbased algorithm that is combined with the methods such as the control volume method, the MAC method, the automatic unstructured mesh generation method makes it possible to simulate many kinds of problems having complex geometries and phenomena with a high accuracy. To confirm the possibility, numerical analyses for some benchmark problems were executed. The results showed that the method achieves high accuracy and has high flexibility even for the flows of high Reynolds number, complicated geometries, moving boundaies and free surface.
\end{abstract}

Key Words: CIVA, Particle Method, Incompressible Fluid, Control Volume Method, Delaunay Tessellation, Unstructured Mesh

1. はじめに

熱流動解析に最も広く使われている数值解析法とし て有限差分法（FDM）があるが、使用するメッシュに 対する制約が厳しく複雑な形状や現象に対しては限界 がある。この問題を解決するため、近年では、メッシュ の扱いを簡略化したり省略した、グリッドレス法[1]や 粒子法[2,3]といったメッシュフリー手法が注目されて いる。これらの手法により非圧緶性流体を解析する場 合に最も問題となるのは質量保存則の取り扱いである。 最近注目されている粒子法では、粒子密度を一定にす ることにより質量保存則を考慮している。しかし、こ の方法では、粒子数が少ないと質量と運動量の保存則 を同時に满足させることが難しいものと思われる。一 方、メッシュフリー手法にも適用可能な高精度補間法 のCIVA法[4]は、補間に利用する幾何学形状は三角形で CIP法[5]型の三次補間を可能とするため、近年研究の 進んでいるボロノイ/デローニ分割[6]の手法を用いて 対象領域を自動メッシュ分割することができる。この ような自動メッシュ分割に基づく解析手法として、谷 口らはボロノイ分割に基づく手法を提案している[7]。 しかし、本研究では、ボロノイ多角形ではなく、デロー 二三角形に注目し、それを質量保存則のコントロール． ボリュームとして、有限体積法（FVM）に基づく非圧

* 原稿受付 1998 年 9 月 8 日.

*1 正員, (株)東芝原子力技術研究所(雪210-0862 川崎市川崎区 浮島町 4-1).

E-mail : nobuatsu.tanaka@toshiba.co.jp
縮性流動解析手法を提案する。移流項評価は、CIVA -粒子法（CIVA-particle法）を用いる。このような方法 は、実際にはメッシュを作っているため厳密な意味で メッシュフリー手法とは言えないが、コード内で自動 的に行って㧈り、コードを使うユーザーはメッシュを 意識せずに解析を実施できるため、疑似的なメッシュ フリー手法とも考えられる。

一方、本手法は、計算点の移動を許容する非構造格 子を用いた流動解析手法とも考えられる。従来、非構 造格子を用いた方法は、移流項の精度良い評価が困難 であった。CIVA法を用いた方法では、三次元移流問題 に対し、三次から四次精度であることが確認されてお り[8]、本研究は非構造格子を用いた流動解析手法の高 精度化という側面もある。つまり、粒子法などのメッ シュフリー手法は、新しい手法であるため、実用的な 解析を行うには、今後更に精度・安定性などの検討が 必要である。そのため、本解析コードは、基本アルゴ リズムはあえてメッシュフリーの手法をとらず、実績 のあるFVMやMAC法を採用した。このことにより、従 来の資産を生かしつつ、メッシュフリー型の汎用性と CIVA法の高精度性を两立が可能となる。

以上の観点から、本論文ではCIVA法に基づく非圧縮 性流動解析手法の一例を提案するとともに、ベンチマー ク問題を解析することによりその基本アルゴリズムの 妥当性の確認問題点を明らかにすることを目的とする。 
2. 解析手法

ここでは、CIVA法を用いて非圧縮性流体解析を行う アルゴリズムについて説明する。

2.1 非圧縮アルゴリズム 非欧縮性流体を対象とし、 粒子の移動を考慮する場合の支配方程式は以下の 3 つ の式となる。

$$
\begin{aligned}
& \frac{d \boldsymbol{x}}{d t}=\boldsymbol{u} \\
& \nabla \cdot \boldsymbol{u}=0 \\
& \frac{\partial \boldsymbol{u}}{\partial t}+(\boldsymbol{u} \cdot \nabla) \boldsymbol{u}=-\nabla p+\frac{1}{\operatorname{Re}} \Delta \boldsymbol{u}
\end{aligned}
$$

メッシュフリー手法により非圧縮性流体を解析する 場合に最も問題となる質量保存則の評価は、自動メッ シュ分割法とFVMの組み合わせにより評価する。自動 メッシュ分割の方法も様々提案されているが、ここで は、2.2節で説明するデローニノボロノイ分割法を用い てコード内で自動的に処理する。全体アルゴリズムは、 MAC法[9]をベースとした図1に示す方法を用いた。

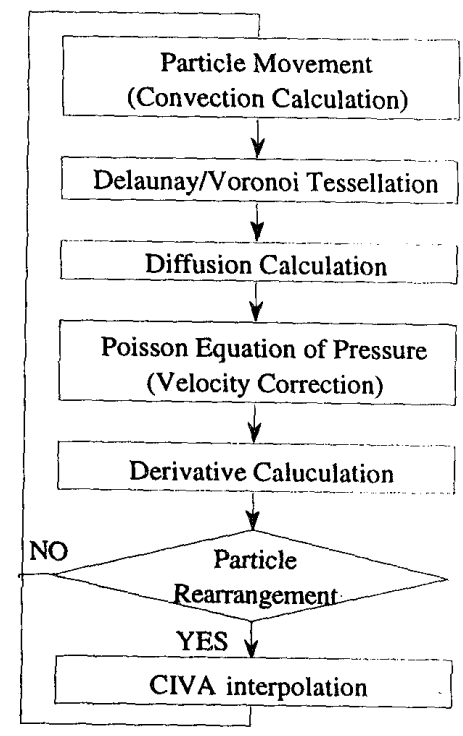

Fig.1 MAC based algorithm

FVM+MAC法では、ポアソン方程式は、コントロー ル・ボリューム $\Omega$ で積分され(4)式のようになる。

$$
\int_{\partial \Omega} \nabla p \cdot d \boldsymbol{n}=1 / \Delta t \int_{\partial \Omega} \tilde{\boldsymbol{u}} \cdot d \boldsymbol{n}
$$

ここで、 $\int_{\partial \Omega} d n$ は境界面での面積分を表し、 $\tilde{u}$ は流速 の予測值である。そのコントロール・ボリュームとし
ては、ボロノイ多角形（図2）を用いることもでき[7]、 低レイノルズ数流れでは解析も可能である（図3はレイ ノルズ数 $(\mathrm{Re})=10^{2}$ のキャビティ流れの例）。しかし、 圧力と流速定義点が同一点上にあるため、玨力解が空 間的にチェッカーボード状に振動し、高レイノルズ数 の流れを解くことは困難となる。この問題を解決する には、有限要素法（FEM）で研究されているような安 定化手法を組み込む必要がある。また、この方法では、 境界上に流速定義点がないため、CIVA法で利用する微 係数に対する境界条件も与えにくい。

一方、本研究では、これらの問題を解決するため、 質量保存則に関するコントロール・ボリュームとして、 ボロノイ多角形を用いるのではなく、それと相対なデ ローニ三角形を用いる。更に、圧力定義点として、そ の三角形の重心位置に仮想的な圧力定義点を設ける

（図4）。この点は三角分割を行って初めて定義点が現 れるものとなる。このようなデータ配置は、スタガー ド型であり圧力の振動を抑えることができる。(4)式の 仕力ポアソン方程式は、初期值を粒子上の值から与え て解く。その解より、粒子速度を修正し、粒子の压力 は補間で求め直す。また、拡散項と流速修正における 圧力勾配の評価は、三角形の重心点よりなる多角形を コントロール・ボリュームとして評価した。

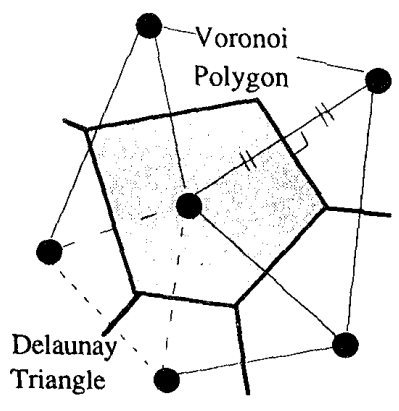

Fig.2 Voronoi/Delaunay

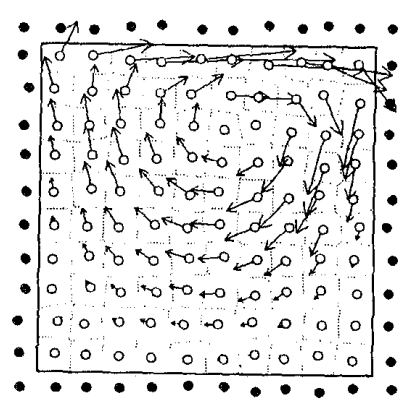

Fig.3 Particle velocity by tessellation Voronoi based algorithm $\left(\operatorname{Re}=10^{2}\right)$

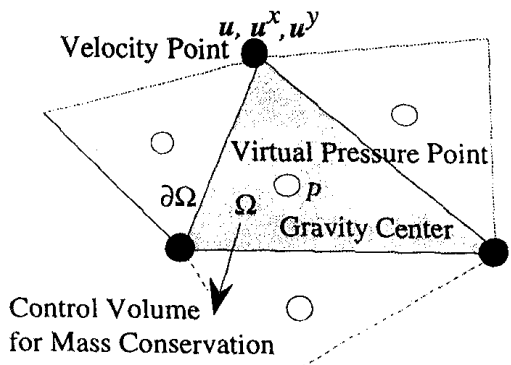

Fig.4 Control volume for mass conservation 
2.2 自動メッシュ分割 上記のように、領域のメッ シュ分割はデローニ/ボロノイ分割法を用いてコード 内で自動的に行う。デロー二三角分割の基本アルゴリ ズムは参考文献[6]のものを利用した。また、ボロノイ 分割は、各辺の垂直二等分線から棈成できる。ただ、 このような自動メッシュ分割方法は、現在、研究が進 められている段階であり、特に、三次元の場合、更な る研究が必要である。

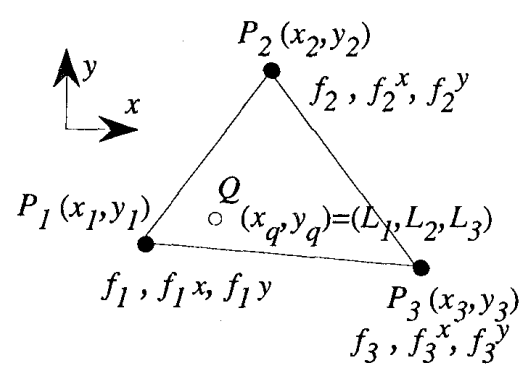

Fing.5 Coordinates for 2-D CIVA

2.3 CIVA法とCIVA-粒子法 計算点再配置の際に必 要となるデー夕補間にはCIVA法を用いる。そのため、 図5に示すように、計算点上にはスカラー量だけでなく その空間微係数も配備する。

2.3.1 CIVA法 CIVA法では、対称性を考慮し、三 角形内のスカラー量に関する 3 次関数を、面積座標 $\left(L_{l}\right.$, $\left.L_{2}, L_{3}\right)$ 交用いて以下の形におく[4]。

$f\left(L_{1}, L_{2}, L_{3}\right)=\sum_{i=1}^{3} \alpha_{i} L_{i}+d \sum_{j, k=I(j \neq k)}^{3} \beta_{j k}\left(L_{j}^{2} L_{k}+c L_{l} L_{2} L_{3}\right)_{(5)}$

dは1次補間と3次補間の調節パラメータで、本論文で は、 $d=103$ 次補間を用いている。 $L_{1} L_{2} L_{3}$ の項は、三角 形の頂点ではスカラー值、微係数ともに 0 となるため、 頂点上の情報からc-パラメータを与えることはできず、 別の条件により与える必要がある。その他の係数は、c にかかわらず、また、係数に関する連立一次方程式を 解くことなく、以下のように決まるため、計算効率の 点でも有利である。

$$
\alpha_{i}=f_{i}, \beta_{j k}=f_{i}-f_{j}+\left(x_{j}-x_{i}\right) f_{i}^{x}+\left(y_{j}-y_{i}\right) f_{i}^{y}
$$

c-パラメー夕の決め方として、三角形の頂点以外の 計算点の情報を用いる方法や、最小自乗法を用いる方 法も考えられるが、ここではFEMの分野で用いられて いる定曲率条件 $[10,11]$ によっ与える。定曲率条件は、 三角形内の任意の点での微係数が任意の值をとりうる ための条件である。基本的な考え方は、(不完全) 三
次多項式(5)が、完全二次多項式を包含するように与え る[11]。すなわち、cを決めたとき(5)式で与えられる関 数の作る関数空間を $S_{3}^{c}\left(f \in S_{3}^{c}\right)$ とし、完全二次多項 式の作る関数空間を $S_{2}\left(g \in S_{2}\right)$ とすると、

$$
S_{3}^{c} \supset S_{2}
$$

となるようなcを求める。

まず、面積座標を用いて完全二次多項式は、

$$
g\left(L_{1}, L_{2}, L_{3}\right)=\sum_{i=1}^{3} a_{i} L_{i}+\sum_{j, k=1(k>j)}^{3} b_{j k} L_{j} L_{k}
$$

と書ける。頂点上のスカラー值については、

$$
a_{i}=\alpha_{i}=f_{i}, \quad i=1,2,3
$$

で十分であるから、空間微係数だけを考えればよい。 頂点上の微係数に関し、(8)式より $g^{x}, g^{y}$ を計算し、

$$
f_{i}^{x}=g_{i}^{x}, f_{i}^{y}=g_{i}^{y}, i=1,2,3
$$

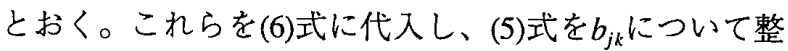
理すると以下の式が得られる。

$$
\begin{aligned}
& f\left(L_{l}, L_{2}, L_{3}\right)=\sum_{i=1}^{3} a_{i} L_{i}+L_{1} L_{2}\left(L_{1}+L_{2}+2 c L_{3}\right) b_{12}+ \\
& L_{2} L_{3}\left(2 c L_{1}+L_{2}+L_{3}\right) b_{23}+L_{1} L_{3}\left(L_{1}+2 c L_{2}+L_{3}\right) b_{13}
\end{aligned}
$$

ここで、面積座標の性質、 $L_{1}+L_{2}+L_{3}=1$ を考慮する と、 $\mathrm{c}=1 / 2$ のときに限り三次多項式(5)は、条件(7)を満足 し、定曲率条件を満たす。三次元の場合も同様に定式 化できる[13]。

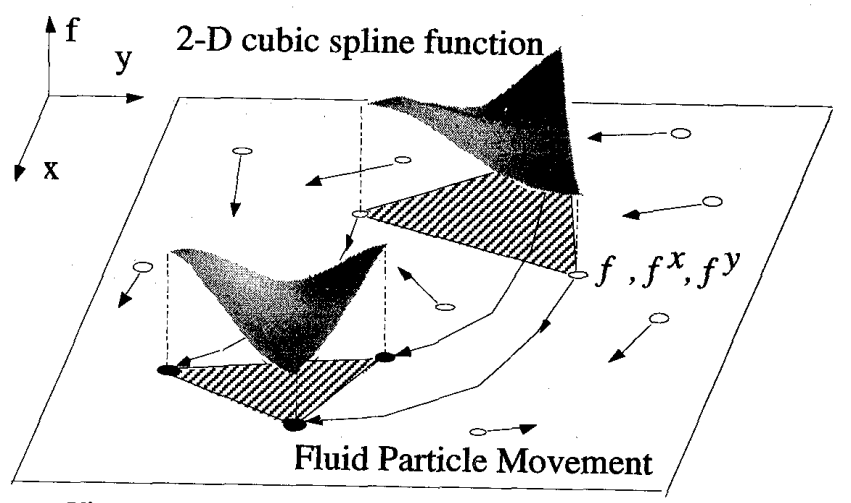

Fig.6 CIVA-particle by means of moving cubic spline

2.3.2 CIVA-粒子法 本コードでは、移流項の評価 （計算点の再配置も含めて）はCIVA-粒子法（CIVAparticle法）[4]で行う。CIVA-粒子法では、計算点上に はスカラー量だけでなくその空間微係数も配備し、計 算点を流れにしたがって移動させることにより移流項 
を評価する。この考え方は、図6に示すように、三次ス プライン関数を流れにしたがって移動させていること と等価である。CIVA-粒子法では、移流は次の 3 つの フェーズで計算され、これをLRI法と呼ぶ。

(C.1) Lagrangian phase ․ ・計算点の移動

(C.2) Rearrangement phase ・ ・ ・計算点の再配置

(C.3) Interpolation phase ・・・デー夕の補間

LRI法では、(C.2)の計算点再配置で、計算ステップ 毎に計算点を初期化すればグリッドレス型、流れに従っ て粒子を移動させ再配置を行わなければ粒子法型のア ルゴリズムとなる。従って、CIP型の三次補間を行って いるCIVA-粒子法は、グリッドレス法、粒子法、CIP法 を統合したアルゴリズムであると考えられる。このよ うな計算点の再配置は、グリッドレス法では固定、粒 子法では流れに従って移動するため、グリッドレス法 や粒子法の計算点は、前ステップの計算点位置と流れ 場に依存すると言える。しかし、CIVA-粒子法は、そ のどちらにも依存しない計算点で解析が可能である。 この場合LRI法は、メッシュフリー型のALE法[12]とも 考えられるが、定式化上は「Rezoning phaseにおける移 流束評価を風上化により計算するALE法」と等価であ ることも確認できる（付録参照）。

2.4 計算点再配置アルゴリズム 上述のように、本 手法は、計算点の再配置を前ステップの計算点位置や 流れ場、粒子密度（非圧縮性条件として用いられるこ ともある[2,3]）とは独立にしたことにより、再配置ア ルゴリズムを自由に選択でき、汎用性が高い。その特 長を示す一例は[13]に示されている。そこでは、ランダ ムに摇らぐ計算点を用いて純粋移流問題を解析してお り、そのような蕨しい条件にもかかわらず良好な結果 が得られている。また、補間に用いる三角形の変形に ついても調べられており、変形に対するCIVA法の強健 さも確認されている。

従来の計算点再配置の方法として最も単純なものは、 前ステップの元の位置に戻す方法である。この場合、 三角分割は 1 回のみ行えばよく計算効率は良いが、移 動境界などは取り扱えない。その他の代表的な方法と しては、粒子密度を一定にする方法[2,3]があるが、こ こでは、新しい手法として電荷モデルを提案する。こ れは、各粒子に電荷を与え、その反発力で粒子密度の 均一化を図る方法で、近傍の粒子からのクーロン力に 従って粒子を移動させる反復を繰り返すことにより、
クーロン力の合計が最少化される位置に再配置するも のである。この方法は、初期の粒子配置決定にも応用 でき、粒子の電荷を変えることにより粒子密度を調整 する解適合法も考えられる。

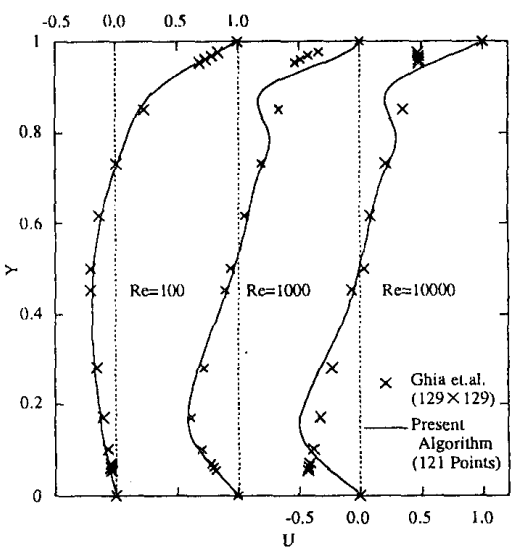

(a) Vertical velocity at horizontal center

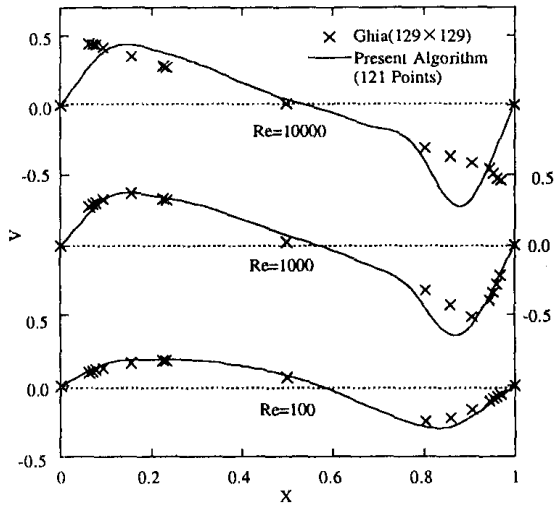

(b) Horizontal velocity at vertical center Fig. 7 Comparison of velocity profile

\section{3. 解析結果}

3.1 正方空間内キャビテイ流れ まず、ベンチマー ク問題として標準的な、正方空間内のキャビティ流れ 問題を解析した。用いた粒子数は境界を含めて121であ る。今回は、(1)式の粒子移動を陽的に評価しているた め時間刻みを大きくとることはできず[4]、クーラン条 件の1/10に固定した。レイノルズ数は $10^{2}, 10^{3}, 10^{4}$ とした。 また、壁面法線方向の微係数に対する境界条件は、流 体側のスカラー值の分布より与えた。まず、各座標方 向中央部での流速をベンチマーク解[14]と比較した。結 果を困7に示す。 $R e=10^{2}$ の場合、結果は良く一致してい る。しかし、Reを大きくしていくと特に流速勾配の大 きな領域で結果がずれている。この点に関し、粒子数 の影響を調べるため、レイノルズ数 $10^{4}$ の場合に、用い る粒子数を 441 と変えた解析を行った。結果を図8に示 す。粒子数を増やすことにより壁面付近の速度勾配は 
界条件の与え方の影響である思われる。これらの点に ついては、今後、検討・改良を行っていく予定である。

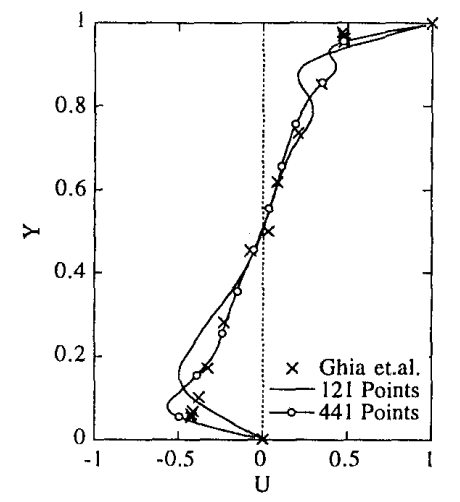

(a) Vertical velocity at horizontal center

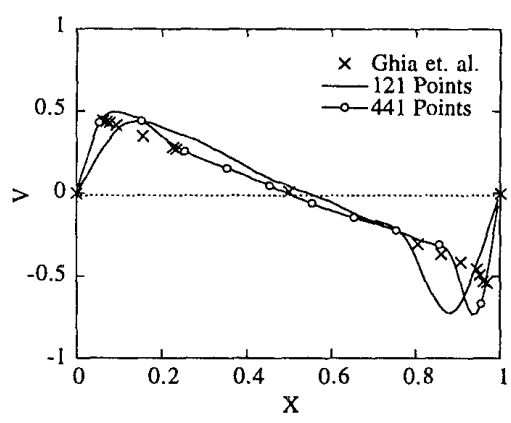

(b) Horizontal velocity at vertical center

Fig. 8 Effect of the variation in particle number $\left(R e=10^{4}\right)$

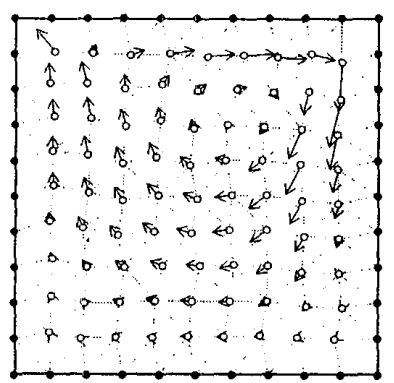

(a) $\operatorname{Re}=10^{2}$

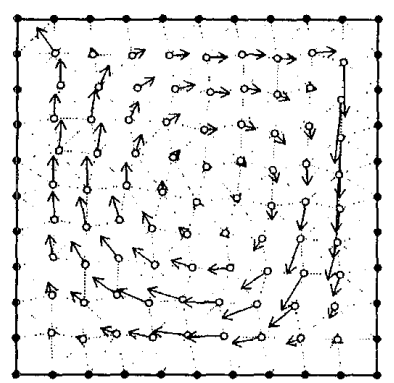

(b) $\operatorname{Re}=10^{4}$
Fig.9 Particle velocity

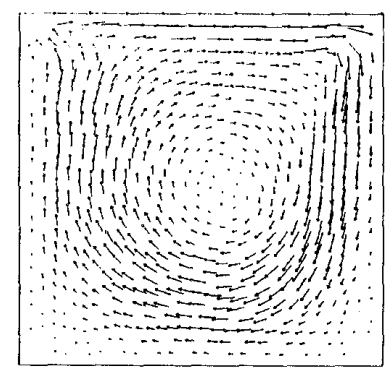

Fig.10 Interpolated velocity

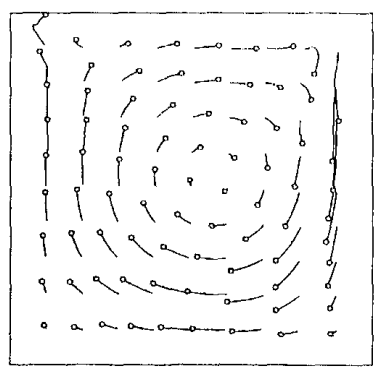

Fig.11 Tracing particles
場である。これらの解析では、粒子の再配置に2.4節で 説明した電荷モデルを採用しているが、毎時間ステッ プ計算点再配置をしており、時間刻みが小さいことと 相まって粒子はほとんど移動しない。そこで、計算点 再配置を行わずに粒子を流れに従って移動させながら 解析を行った。結果を図11に示す。流体の挙動が良く 再現されている。ただし、この方法では図11に示すよ うに、粒子が壁面に接近したり、粒子数の少ない領域 ができたりするため、そのまま解析を継続するのは困 難で、粒子の再配置を行う必要がある。

計算時間の観点から見ると、本手法はプロトタイプ であり計算效率の最適化を行っていないため単純な比 較は出来ないが（タイムステップ毎に初めからメッシュ 生成を実施、非効率なポアソン・ソルバー、等）、ほ ぼFDM（棈造格子）の十倍程度であった。元来、本手 法はFEMとFDMの中間的な手法と考えられるため、ア ルゴリズムを最適化することにより、計算時間も、

FEMとFDMの中間的なものになると考えられる。

3.2 自由液面流れ 次に、自由液面を有する流体の 振動問題[15]を解析した。用いる粒子数は225で、粘性 は0とし、初期条件は図12に示すように与えて静止状態 から計算を開始した。なお、自由液面の境界条件は圧 力を0とし、液面と平行な方向に滑り境界とすることで 与えている。また、計算点再配置は鉛直方向のみ考慮 し、水平方向は固定した。壁面水位の時刻歴を図13に 示す。比較のため、100x150のメッシュを用いたFDMVOFによる結果も含めた。CIVA-粒子法では計算点が 少ないにもかかわらず良好な結果が得られている。ま た、この問題では粘性0であるため、速度ポテンシャル

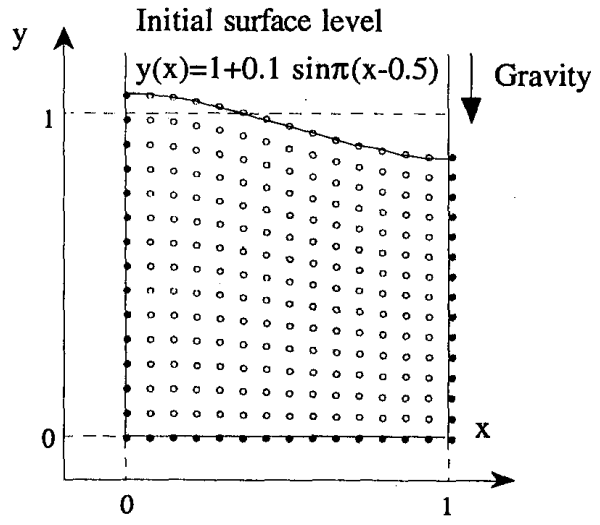

Fig. 12 Free surface sloshing problem

次に、粒子速度の分布を図9,10に示す。図10は

$\mathrm{Re}=10^{3}$ の場合の速度場をCIVA法で補間して求めた流速 


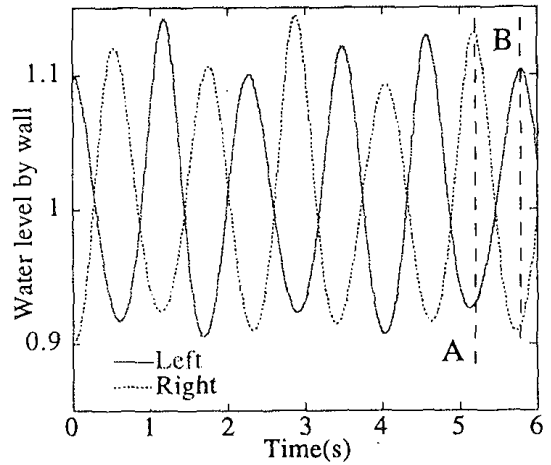

(a) FDM-VOF (100x 150 grid points)

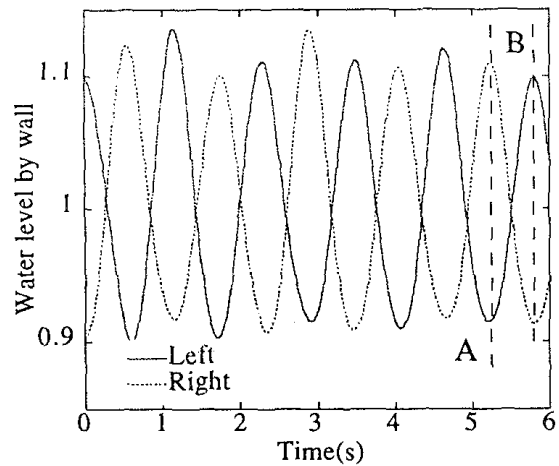

(b) CIVA-particle (225 particles)

Fig. 13 Time history of surface level by left and right wall

Table 1 Comparison of sloshing frequency

\begin{tabular}{|c||c|c|c|}
\hline & Vector potential & FDM-VOF & CIVA-particle \\
\hline \hline Frequency & 0.882 & 0.869 & 0.862 \\
\hline
\end{tabular}
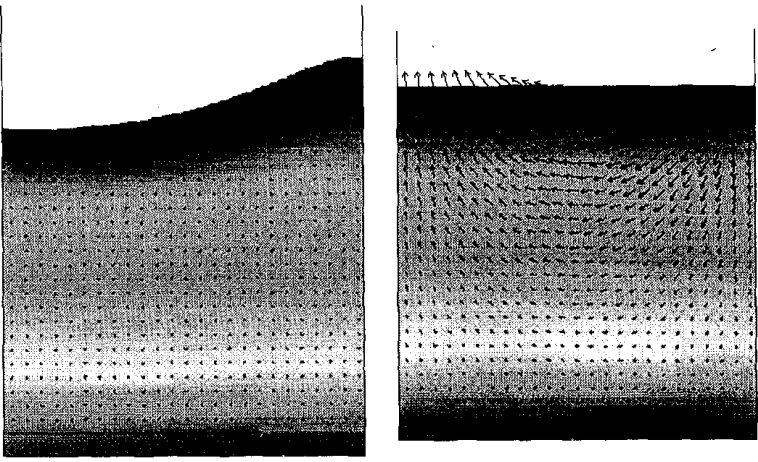

(a) FDM-VOF (Left: at time A, Right: at time B)

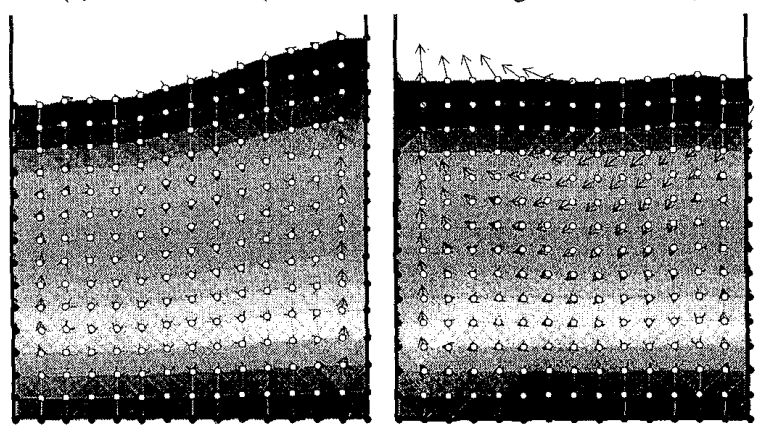

(b) CIVA-particle (Left: at time A, Right: at time B)

Fig.14 Flow vector and pressure distribution
法により振動周期を計算することができる。表1に振動 周期の比較を示す。速度ポテンシャル法は線形理論で あるため、FDM-VOFとCIVA-粒子法とはやや異なった 結果になっているが、FDM-VOFとCIVA-粒子法ではよ く一致している。図13中の時刻A,Bにおける流況が図 14 である。自由液面の挙動が良く再現できている。

\section{3 複雑体系内移動境界問題 次に、より複雑な問} 題の一例として、移動境界を伴う複雑領域内の流れ解 析を行った。問題は、図15に示す領域の回転翼による 流れである。この問題も、上述の電荷モデルを使うこ とにより粒子の間隔を一定に保っている。結果を図 15 に示す。翼により回転流れが形成され、それに伴って 右側に二次渦が生成する様子がわかる。

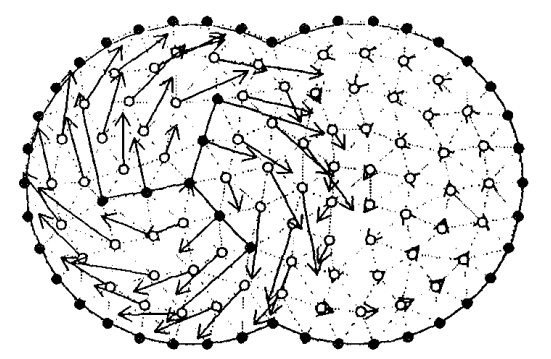

Fig.15 Particle velocity of flow around rotating wings in a complicated geometry $\left(\operatorname{Re}=10^{3}\right)$

$$
\text { 4. まとめ }
$$

高精度補間法CIVA法と粒子法の組み合わせによる非 圧縮性流体解析手法について説明した。その基本アル ゴリズムは、有限体積法、MAC法、デローニ自動三角 分割法、安定化データ配置、計算点再配置アルゴリズ ムなどに基づいており、柔軟で高精度な解析を可能と する。その検証問題として、キャビティ流れ、自由液 面流れ、複雑体系問題、移動境界問題を取り上げ、有 效性を確認した。また、CIVA法におけるc-パラメータ の決め方やCIVA-粒子法とALE法の関係についても考察 を行った。

\section{参考文献}

[1] Batina, J.T., AIAA Paper 93-0333(1993).

[2] 梅垣, 他1名, 数值解析, 43-3 (1992).

[3] Koshizuka, S., 他1名, CFD Journal, 4-1 (1995).

[4] 田中, 機論, 64-620, B (1997).

[5] Yabe, T., 他1名, J. Phys. Soc. Japan, 57 (1988).

[6] 谷口, FEMのための要素自動分割, 森北出版 (1992).

[7] 谷口, 他1名, 機論, 55-513, B (1989). 
[8] 田中, 日本原子力学会1998年秋の大会予稿集(II),G38.

[9] Harlow, F.H., 他1名, Phys. Fluids, 8-12 (1965).

[10] Zienkiewicz, O.C., The Finite Element Method (3rd

Edn.), McGraw-Hill Co. Ltd. (1977).

[11] Bazeley, G.P., 他3名, Proc. Conf. Matrix Methods in

Struct. Mech., Air Force Inst. of Tech., Ohio (1965).

[12] Hirt, C.W., 他2名, J. Comp. Phys., 14 (1974).

[13] Tanaka, N., CFD Journal, 8-1 (1999).

[14] Ghia, U., 他2名, J. Comp. Phys., 48 (1982).

[15] Ramaswamy, B., J. Comp. Phys., 90 (1990).

\section{付録 CIVA-粒子法とALE法}

ここでは、CIVA-粒子法におけるLRI法とALE法の関 係について考察を行う。まず、図16に示すように、空 間(固定)座標 : $\boldsymbol{x}(\boldsymbol{x}, \boldsymbol{y})$ 、物質座標 : $X(X, Y) 、 \mathrm{ALE}$ 基準(移 動)座標： $\chi(\chi, \xi)$ と座標系を設定する。以上のそれぞれ の座標に対し、移流方程式は以下のように表される。

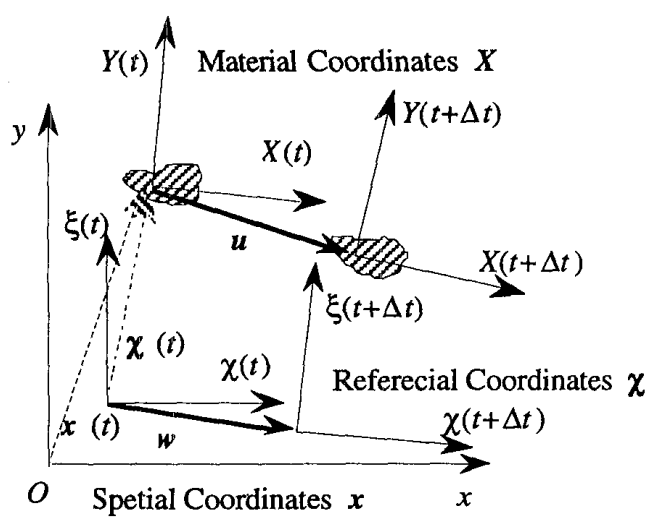

Fig. 16 Coordinate system

$$
\begin{array}{ll}
\text { 固定座標表示 } & \left.\frac{\partial f}{\partial t}\right|_{x}+(\boldsymbol{u} \cdot \nabla) f=0 \\
\text { 物質座標表示 } & \left.\frac{\partial f}{\partial t}\right|_{x}=0 \\
\text { ALE座標表示 } & \left.\frac{\partial f}{\partial t}\right|_{\chi}+(\boldsymbol{c} \cdot \nabla) f=0
\end{array}
$$

ただし、ALE座標系での座標移動速度を $\boldsymbol{w}$ とし、 $\boldsymbol{c}=\boldsymbol{u}-\boldsymbol{w}$ とおいている。

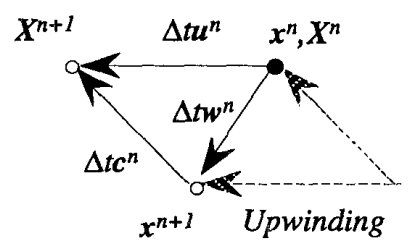

Fig. 17 Coordanates in LRI
LRI法 CIVA-粒子法におおけ LRI法の各フェーズは、 以下の評価を行っていることになる（図17参照）。

(C.1) Lagrangian phase （20)式を評価し、時間ステッ プを $\mathrm{n} \rightarrow \mathrm{n}+1$ に進める。

$$
\begin{aligned}
& X^{n+1}=X^{n}+\Delta t u=x^{n}+\Delta t u \\
& f\left(t^{n+1}, X^{n+I}\right)=f\left(t^{n}, X^{n}\right)
\end{aligned}
$$

(C.2) Rearrangement phase 計算点の再配置を行い $(\mathrm{n}+1)$ 時刻の計算点の位置 $x^{n+1}$ を決める。

$$
x^{n+1}=x^{n}+\Delta t w=X^{n+1}-\Delta t c
$$

(C.3) Interpolation phase 位置 $x^{n+1}$ におけるデー夕 $f\left(t^{n+1}, x^{n+1}\right)$ を求めるため、補間を行う。

$$
f\left(t^{n+1}, x^{n+1}\right)=f\left(t^{n+1}, X^{n+1}-\Delta t c\right)
$$

ここで、(22)式を用いると以下のようになる。

$$
f\left(t^{n+1}, x^{n+1}\right)=f\left(t^{n}, X^{n}-\Delta t c\right)
$$

$X^{n}=x^{n}$ を考慮すると、LRI法は(C.1)〜(C.3)の手順 により以下の式を評価しているといえる。

$$
f\left(t^{n+1}, x^{n+1}\right)=f\left(t^{n}, \boldsymbol{x}^{n}-\Delta t c\right) .
$$

Fig. 18 Coordinates in ALE

ALE法 一方、ALE法は、移流問題を陽的に評価す る場合、以下の 2 つのフェーズより成る[12]。

(A.1) Lagrangian phase

(A.2) Rezoning or Convective flux calculation phase

これらの各フェーズは、Fractionl step的な時間ステッ プの進め方を行い、以下の評価を行う（図18参照）。

(A.1) Lagrangian phase (20)式を評価するが、時間ス テップは完全に進めず中間段階Lでの值とする。

$\boldsymbol{x}^{L}=\boldsymbol{x}^{n}+\Delta \boldsymbol{t u}$

$f\left(t^{L}, X^{L}\right)=f\left(t^{n}, X^{n}\right)$

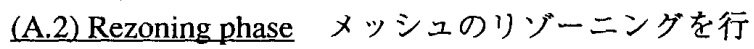


い、(n+1)時刻の計算点の位置 $\boldsymbol{x}^{n+1}$ を決定する。

$$
x^{n+l}=x^{n}+\Delta t w=x^{L}-\Delta t c
$$

更に $(\mathrm{n}+1)$ 時刻の計算点の位置でのデー夕を求めるた め、(21)式を評価（移流束評価）する。一般に、この評 価は、(21)式を離散化して行うが、ここでは式(21)を風 上化により評価することを考える。その場合、座標移 動を考慮して、以下の式を評価することになる。

$$
f\left(t^{n+1}, \chi^{n+1}\right)=f\left(t^{L}, \chi^{L}-\Delta t c\right) .
$$

いま、

$$
f\left(t^{L}, \chi^{L}\right)=f\left(t^{L}, X^{L}\right)
$$

$$
\begin{aligned}
f\left(t^{n+1}, \chi^{n+1}\right) & =f\left(t^{L}, X^{L}-\Delta t c\right) \\
& =f\left(t^{n}, X^{n}-\Delta t c\right)
\end{aligned}
$$

従って、移流束を風上化により評価する場合、

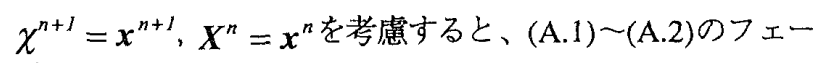
ズは、以下の式を評価しているといえる。

$$
f\left(t^{n+1}, x^{n+1}\right)=f\left(t^{n}, x^{n}-\Delta t c\right)
$$

式(26)と(32)より、LRI法は、「Rezoning phaseにおけ る移流束評価を風上化により計算するALE法」と等価 であることがわかる。

が成り立つので、式(29)は式(27)を考虑して以下のよう

に変形できる。 